\title{
"I mean, I like English even better than Turkish": English-speaking German-Turkish Students as Multilingual Transnationals
}

\author{
Işıl Erduyan a * (iD) \\ ${ }^{a}$ Boğaziçi University, Department of Foreign Language Education, Istanbul 34342, Turkey \\ Received 29 March 2019 | Received in revised form 24 June 2019 | Accepted 18 July 2019
}

\section{APA Citation:}

Erduyan, I. (2019). "I mean, I like English even better than Turkish": English-speaking students as multilingual transnationals. Eurasian Journal of Applied Linguistics, 5(2), 255-268. Doi: 10.32601/ejal.599250

\begin{abstract}
Focusing on a group of multilingual German-Turkish students enrolled at an urban high-school in Berlin, this paper inquires how ELF identities and transnational experiences inform each other. Semistructured, audio-recorded interviews conducted as part of a larger project (Erduyan, 2019) are analyzed through microethnographic lenses informed by a scalar approach. Following Lam (2009) and Maloney \& De Costa (2017) the analyses focus on the local, translocal, and transnational scales that permeate students' narratives. Findings suggest that being ELF users/speakers help Turkish students fill in a gap that they perceive they cannot fill in by being Turkish or German speakers alone, that of being cosmopolitan, global citizens with transnational experience. Findings also suggest the changing meanings of homeland for Turkish students - from the traditional, monolingual, provincial Turkey to a more urban, cosmopolitan Turkey. The inevitable implications of these changes for identity construction are discussed further in the article.

(C) 2019 EJAL \& the Authors. Published by Eurasian Journal of Applied Linguistics (EJAL). This is an open-access article distributed under the terms and conditions of the Creative Commons Attribution license (CC BY-NC-ND) (http://creativecommons.org/licenses/by-nc-nd/4.0/).
\end{abstract}

Keywords: scales; translocality; interaction analysis; ELF; migration

\section{Introduction}

\subsection{Multilingualism with English}

While ELF as a field of study has been continuously expanding in scope, the multilingual turn in SLA and its related disciplines have established its place in the last couple of decades resulting in a rapid expansion in research base, methodological and theoretical span (e.g., May, 2014). The interface between these two areas of scholarship has been acknowledged for quite some time (e.g. House, 2003; Seidlhofer, 2017) leading research into readily embracing the notion "multilingualism with

\footnotetext{
* Corresponding Author. Tel.: +90-212-359-4612

E-mail address: isil.erduyan@boun.edu.tr
} 
English," a term coined and discussed by Jessner (2006) in an entire chapter of her volume. As Seidlhofer (2017) writes, lingua franca interactions are multilingual by definition, as "they bring into contact and mediate between linguacultures of two or more speakers" (p. 392). To this end, Jenkins (2015) has proposed a framework in which multilingualism encompasses ELF, and argues for a better conceptualization of ELF communities by paying attention to their transience and mobility against the background of the multilingual reality of our day.

\subsection{The Present Study}

The present study aligns with this thought, and locates users/speakers of English as a Lingua Franca (henceforth ELF users/speakers) as, first and foremost, multilingual individuals, who have become multilinguals due to their families' migration histories. Rather than solely focusing on their ELF trajectories though, this paper is concerned with situating the ELF user/speaker identity within students' transnational experience at large. In order to understand how this relationship works, the study takes a scalar approach (Lam, 2009; Maloney \& De Costa, 2017) and focuses on the local, translocal, and transnational scales as informing students' narratives. Starting with investigating the meanings of being residents of a global city like Berlin, and moving onto the analyses of changing meanings of the homeland for them, the paper finally investigates the construction of being ELF users/speakers. Before moving onto these analyses, below I present the theoretical framework in which this paper is situated.

\subsection{Theoretical Framework}

Scalar analysis has received significant attention in applied linguistics in recent years (e.g. Blommaert, 2007, 2010; Blommaert, et al., 2005; Canagarajah \& De Costa, 2016; Collins, et al., 2009). As Maloney and De Costa (2017) depict, there seems to be two major lines of thinking in incorporating scales into language analyses: scales as timescales or scales as "nested social contexts" (p.38). The former approach is not new in educational research. The notion of timescales has been acknowledged within the framework of Vygotskyan sociocultural theory for a long time (Lantolf, 2000a; Lantolf \& Thorne, 2006; Lantolf and Poehner, 2014). Sociocultural theory, Lantolf and Thorne (2006) write, is not only a theory of social interaction, but "a framework through which cognition can be systematically investigated without isolating it from social context" (p.1). One of the major tenets of the sociocultural theory in analyzing cognitive processes as inseparable from the social context is the genetic method, which argues that developmental changes in mental functioning take place across multiple and interrelated genetic domains. The slowest change in human development has occurred in the phylogenetic domain across millions of years and has separated humans from other organisms. Next, Vygotsky discusses the domain of sociocultural history, which concerns the emergence of material and symbolic tools and the production of culture through differentiation among the ways of using these tools, 
such as language. The ontogenetic domain is situated at the intersection of these two domains and concerns the individual development through appropriation and integration of language and other mediational resources. Finally, the microgenetic domain concerns the local, moment-to-moment learning processes that span much shorter time frames as in learning particular features of a language (Lantolf, 2000b).

In a similar conceptualization, Lemke (2000) and Wortham (2004, 2006) have extended the analysis of timescales to classroom learning and social identification processes. Lemke (2000) contends that the fundamental units of analysis in the classroom are processes that take place simultaneously on multiple timescales, and identifies more than 20 such timescales that play roles in classroom identification processes simultaneously. While some of these span milliseconds as in the duration of neuron processing in learning, others might take multiple years as in the implementation of curricula. In Wortham's (2003, 2006) analyses, meanwhile, the sociohistorical timescale in the classroom context encompasses the widely circulating categories of identity, such as ethnicity, gender, or social class, which endure and develop on the "sociohistorical" timescale of decades and centuries (Wortham, 2003, p. 229). Students mediate the sociohistorical timescale through their unique developmental trajectories within their own ontogenetic timescales. Yet, they also develop in the course of "distinctive activities, structures, and styles" (Wortham, 2003, p. 229) of individual classroom and school settings, which exist and develop over weeks, months, semesters, and years, i.e. within the mesolevel timescales. Finally, Wortham $(2003,2006)$ analyzes the microgenetic timescale in relation to the most local level of interaction in the classroom that takes seconds, minutes, a certain task time or a lesson hour. In the $9^{\text {th }}$ grade English lessons that he analyzed, Wortham (2003, 2006) demonstrates how sociohistorically developed identity models such as gender stereotypes, or those derived from the widely circulating systems of individualism and collectivism, intensify locally across weeks and months in the classroom "through repeated microgenetic enactments in particular classroom conversations" (p. 232).

The latter approach to scales that Maloney and De Costa (2017) identify, meanwhile, focuses on scales as social constructions. In this sense, as Blommaert (2010) put it, "[d]ifferent scales can interact, collaborate and overlap or be in conflict with one another, because each time there are issues of normativity at play" (p. 37). Based on this understanding, and extending Lam's (2009) framework, Maloney and De Costa (2017) identify the interaction among local, translocal, and transnational scales across student writings, emphasizing that multiple scales inform the language development of transnational students. They specifically focus on the imagined communities that make up three scale levels. The local scale that concerns the surrounding city and its institutions, the translocal scale that concerns "imagined community of other transnationals living within the same national borders"; and the transnational scale which refers to the "the imagined community of speakers globally or those of the same ethnic heritage" (p. 39). 
The present paper will adopt this approach and attend to these three scales in its analyses of interview accounts with German-Turkish high school students. The guiding question in these analyses is How does their transnational experience inform students' construction of multilingual identities in an ELF context?

\section{Method}

The data analyzed in this paper is part of a larger linguistic ethnographic study that has been reported across various papers and a volume (e.g. Erduyan, 2017, 2019). Focusing on five German-Turkish high school students enrolled in a mainstream Gymnasium in Berlin, the study at large analyzes the multilingual construction of identity across language classes (German, Turkish, English). In this paper, data drawn from interviews with four of these participants will be presented. Of these four, three are female, Berlin-born students (Deniz ${ }^{\dagger}$, Ela, Simla) and one is a Turkish-born male student (Mert) who migrated to Berlin with his family while in the second grade.

Regular classroom observations that spanned three academic semesters were supplemented by field notes and audio-recordings of participants' interactions. The present paper, however, focuses on the semi-structured interview data that come from 8 different interviews conducted with the participants and their language teachers at school and lasted from 45 minutes to 2 hours in duration. The interviews were conducted at various different points in the fieldwork timeline, audiotaped and transcribed for a closer linguistic ethnographic analysis (see Appendix for transcription conventions). Interview questions spanned a range of reflective questions that elicited participants' extended responses to questions concerning identity and those that focused on more specific, event-related topics.

The analyses in this paper adopt the notion of scales as an analytical tool as framed by Lam (2009) and De Costa \& Maloney (2017), and as depicted in the previous section. The local, translocal, and transnational scales will be under focus in each section below as informing participants' discourses in the interviews. Different than De Costa \& Maloney (2017), who focus on the imagined communities as scale makers, the analyses in this paper will treat these three scales as three different levels of understanding the participants' discourses.

\subsection{The Local Scale of Berlin: Constructing Attachment to the City}

In the realm of understanding participants' linguistic identity construction processes, my interviews with them involved a focus on inquiring their takes on being residents of a city like Berlin. All of them openly and strongly stated their attachment to the city by particularly centering on its big-city-like qualities, such as liveliness of streets. Among them, Mert and Deniz gave quite articulated personal accounts. I asked Mert whether he could see himself live in another city in Germany:

1 Mert: yok (.) Berlinden başka bir şehirde yaşayamam

\footnotetext{
$\dagger$ All names are pseudonyms.
} 
2 Işıl: Berlinde Kreuzbergden baska yerde yaş-

3 Mert: yok (.)Berlin(.) yani illa Kreuzberg olmasına gerek değil [öyle bi ayrım yapmam da 4 Işıl:

[herhangi bi yeri

5 Mert: başka şehirlere de gittim Berlin gibi değil yaa [...] Essene gittim mesela Allahım gittim $>1-2$ haftalığına kalmaya gittim $<2$ saat sonra geri döndüm [..] dayanamadım ya: 7 insan görmedim [...] insan yoktu dışarıda >bunu herkes söylüyo < Berlinde yaşayan bir

8 insan başka bir yerde öyle kolay kolay yaşayamaz

1 Mert: no (.) I can't live in a city other than Berlin

2 Işl: in Berlin in any place other than Kreuzberg [live]-

Mert: no (.)Berlin(.)I mean it doesn't have to be Kreuzberg [I don't make such a distinction

$$
\text { Işl: } \quad \text { [anywhere }
$$

Mert: but I've been to other cities but they're not like Berlin ma:n [...] I went to Essen for instance my God I went $>$ I went there to stay for 1-2 weeks $<$ I returned after two hours [...] couldn't take it ma:n didn't see a human being [...] there was nobody on the streets $>$

everybody says this $<$ a person who lives in Berlin cannot live in any other place easily anymore

Mert's opinions about living in Berlin are heavily marked by references to the local scale of the city. He first clarifies that he does not necessarily mean Kreuzberg when he says living in Berlin, thus referring to a larger scale than the immigrant-heavy neighborhood at the heart of Berlin. He then explains that Berlin is different than any other city in Germany, and to support this stance, he draws on an anecdote in which he compares Berlin with Essen. His framing of this narrative with my god and his exaggerated tone as in there was nobody on the streets further enhances his stance.

In a similar vein, in my interview with Deniz, I bring up the topic of moving to another neighborhood in Berlin:

9 Işll: hiç kendini sen başka bi mahallede yaşarken düşünebiliyo musun Berlinde?

10 Deniz: alışamam ya:

11 Işıl: zum Beispiel Spandau [joking]

12 Deniz: nei::n (.) hayatta ben buralardan çıkma:m (.) annem diyodu Mitteye taşınalım

13 Işıl: ha orası da temiz güzel nezih

14 Deniz: orayı bilmiyom ya:: istemiyom ben Kreuzbergden hiç çıkmak istemiyom (.) hele

15 burda Schlesisches Tor Schlesiden hiç çlkmak istemiyom

16 Işll: neden? orda ne var?

17 Deniz: seviyom buraları

18 Işıl: canlılığı $\mathrm{mı}$ hoşuna gidiyo?

19 Deniz: evet yani

9 IŞll: can you ever imagine yourself living in another neighborhood in Berlin?

10 Deniz: I can't get used to it ma:n

11 Işll: for example Spandau [joking]

12 Deniz: no:: (.) I can no way in life lea:ve here (.) my mom used to say let's move to Mitte

13 Işl: oh yes that's also clean nice classy

14 Deniz: I don't know about it ma::n I don't want it I don't want to leave Kreuzberg at all (.)

15 particularly here at Schlesisches Tor I don't want to ever leave Schlesi

16 Işll: why? what's up with it?

17 Deniz: I like it here 
18 Işl: do you like the liveliness?

19 Deniz: I mean yes

Deniz's reaction to my sarcastic comment in line 11 and her following statement where she states she can no way in life leave here indicate her sense of the local space of Schlesisches Tor, which is a small part of Kreuzberg with vibrant multicultural life and which is where Deniz lives with her family. As in the case of Mert, Deniz constructs her rationale around not being able to live anywhere else, which she repeats four times in lines 10,12,14,15. Both Mert and Deniz indicate a strong sense of attachment to the city through emotionally laden comments that they construct through language.

In addition to these accounts, the participants have also stated their affiliations with the city in a rather direct way, simply by focusing on "being from Berlin." While it is quite common to hear various self-affiliations among young German-Turkish students of this age group, affiliation with their city of residence in particular is much less commonly heard among the Turkish immigrants living in Europe (see Yağmur, 2009; 2016), although it is quite conventional in Turkey. The participants express their affiliation with Berlin in the same way that they would do if they were residing in Turkey: by adding the Turkish derivational suffix, $-l(i)$ to the word Berlin to mark relation. Ela explains her affiliation in a rather detailed way:

20 Ela: Zaten Türkiyeye gidince Almancı diyolar gıcık oluyom [...] buraya geliyoz yabancı

21 diyolar oraya gidiyoz Almancı diyolar [smiles] öyle bi şey var [...] ben zaten kendi

22 memleketim şey Erzurum (.) oraya hiç gitmedim [...] aslında mantık olarak Berlinliyim

23 artık hani (.) burda doğmuş büyümüşüm

20 Ela: When I go to Turkey they call me Almancr I'm so pissed off [...] we come here and they

21 call us foreigners we go there and they call us Almancr [smiles] there's such a thing [...] I

22 mean my own hometown is Erzurum (.) I've never been there [...] in fact logically speaking

23 I'm from Berlin actually (.) I was born and raised here

Ela refers to a well-known Turkish tongue-twister-like expression that is used to describe German-Turks, i.e. "Türkiye'de Almancl, Almanya'da yabancı." Her smile and her following comment there is such a thing indicate that she is actually aware of the intertextual reference that she makes with this usage and she does not really subscribe to it. In her next sentence, she refers to her hometown, by which she means the town where her family has come from and that she has never been to. As her line of thinking continues, she finally uses Berlinli to describe herself, adding also the rationale that she was born and raised here. The way she constructs this as in, in fact logically speaking I'm from Berlin actually, gives the impression that she is also aware of the way Berlinli sounds unusual.

In my interviews with her, Simla sounds more confident about being from Berlin, but she also gives the impression that she is aware of the uncommonness of this ascription herself:

24 Simla: ben kendimi Türk kökenli bir Alman vatandaşı olarak tanımlıyorum [...]

25 eskiden sorarlardı bana annemin ilk çocuğuyum ve kızım (.) herkes sorardı 
Simla describes herself in a rather formal way at the beginning, but then she adopts a more animated tone with her insertion of the exact quotes that she used as a child in line 26 . What she means here is how she immediately tells people that she is from Berlin after saying two introductory statements about herself. Said in a faster tone, her quote I'm from Berlin sounds more defensive than a regular statement. Together with Ela's statement in the previous excerpt, being Berlinli appears as one way in their discourse in which the participants show their affiliation with the city.

All in all, participants make clear references to the local scale of Berlin in their interview accounts, and they indicate a sense of attachment to the city. They construct this discourse through exploiting remarkably articulate forms of speech, with their exaggerated tone as in the use of $m y$ god, extending vowels, or repetitions. They also incorporate Berlinli in their self-description, a pretty common form of marking affiliation with a place in the Turkish language, but is much less commonly used in the case of places outside Turkey. Their acknowledgement of the unusualness of this ascription seems to suggest that, their affiliation with the local scale of Berlin points to a sense of belonging to a large vibrant city, in a native sense that Turks normally would do with their homeland in Turkey. In a way, this sense is perpetuated by the multicultural 'global city' quality of Berlin, with certain neighborhoods like Schlesisches Tor being home to people from a large number of ethnic and national backgrounds.

\subsection{The Translocal Connection: Changing Meanings of Turkey}

As part of the $9^{\text {th }}$ grade curriculum in the Fall semester, the Turkish teachers at school organized a trip to Istanbul, which I had a chance to join due to my additional role at school as a materials developer in the Turkish program. As an important part of this excursion, the teachers organized a visit to a well-known state high-school in central Istanbul. In addition to observing some classes, the students had a chance to socialize with their local peers, playing and chatting with them. At one point in these observations, the two groups had a classroom discussion on migration. In our interview at the end of the year back in Berlin, I ask Ms. Kaya (MK), the Turkish teacher, about her opinions on the trip and her take on the encounters students experienced. Ms. Kaya narrates this discussion and its aftermath with her students in the following way:

MK: şimdi bizim ögrencilere dedim ki ben=göç konusu şimdi siz dedim bakın göç etmiş ailelerin çocukları olaraktan Almanyada yaşıyosunuz (.) Berlinde yaşıyosunuz Almanyanın başkenti dört milyonluk bi nüfus ve biz şimdi burada İstanbulda büyük bi metropoldayız (.) yani dünyada sayılı büyük şehirlerden birisi de İstanbul (.) fakat burada yaşayan insanlar da göçü yaşamış yani yerli İstanbullu bulmak zor Işıl: hı hı 
33 MK: yani belki bir iki kuşak geriye gittiğin zaman mutlaka ya Anadolunun bi yerinden geliyordur ya yurtdışından geliyordur ama genelinde Anadolunun bir yerlerinden geliyordur yani Ișll: tabi tabi

MK: orada göçü nasıl yaşıyosunuz (.) öğrencilerle bizim öğrenciler kendi göç hikayelerini anlattı ve Beşiktaştaki öğrenciler de kendi hikayelerini anlattılar çok ilginç şeyler var Işıl: tabi tabi

MK: ve kesişen şeyler var

Işl: muhakkak

MK: konu olarak da o yalnızlık büyük şehirde yaşamın verdiği sorunlar

Işll: evet

MK: işte kuşaklar arası çatışma yani çok ilginçti

MK: well I told our students that=the topic of migration I told them listen you are living in Germany as children of families who migrated (.) living in Berlin the capital of Germany a city of four million and we are now here in a large metropolis (.) I mean one of the few large cities in the world is Istanbul (.) but people living here have also experienced migration I mean its difficult to find natives of Istanbul

Issl: $u h$ huh

MK: I mean perhaps when you go back one or two generations they come either from somewhere in Anatolia or somewhere from abroad but generally they come from somewhere in Anatolia

Işll: of course of course

MK: how do you experience migration there (.) our students told their migration stories and the students at Beșiktas told their own stories there are very interesting things

Işl: of course of course

MK: and there are intersecting things

Işll: for sure

MK: and as topics that loneliness problems that come with living in a big city

Ișll: yes

MA: like generation clash I mean it was very interesting

The connection that Ms. Kaya seems to have drawn in her class is the similarity between Istanbul and Berlin in terms of being two large cities receiving immigrants, the difficulty of finding genuine natives in both, and the similarities in residents' experiences as immigrants. In this account, Istanbul appears more similar to Berlin than to Anatolian towns that most of the students' families have come from. Thus, Ms. Kaya draws on a translocal scale in describing her take on this experience they went through together in Istanbul. This perspective is a novel way to approach migration from Turkey, and at its core lies the connection drawn between Berlin and Istanbul as two large cities. Instead of the traditional homeland rhetoric, Ms. Kaya's account draws on a renewed sense of connecting with the homeland.

Mert was one of those students who were influenced by the trip to a great extent. In our end of the year interview, he gives the following account:

45 Mert: Türkiyeden döndügümü düşünmüyorum hala Türkiyedeyim o etkideyim hala

46 Ișl: ha: gezinizde doğru:

47 Mert: gezi olsun yaz tatili olsun [..] kendimi Türkiyede gibi hissediyorum [...]

45 Mert: I don't think I've really returned from Turkey I'm still in Turkey I'm still in that mode

46 Işll: o:h you mean on your trip ri:ght 
Mert expresses his feelings about returning from Turkey in a rather metaphorical, almost poetic way. He probably means in his turns here that he still remembers the summer holiday and the Istanbul trip so vividly, and they still occupy his mind, drawing on a translocal scale. This leads me into questioning whether it was his first time visiting Istanbul.

48 Iş̧1: senin ilk [seferin miydi İstanbulda?

49 Mert: [benim İstanbulda ilk seferimdi yani=

50 Iş̧l: =nasıl buldun?

51 Mert: bi çok şehre gittim ama Adanayla kıyaslayabileceğim bi şehir yani Adanayı hiçbir

52 şehirle kıyaslamazdım ama İstanbulu kıyaslarım

53 Işll: hmm

48 Ișll: was this your [first time in Istanbul?

49 Mert: [it was my first time in Istanbul I mean=

$50 \quad$ Işll: $=$ how did you find it?

51 Mert: I've been to many cities but it's a city that I can compare with Adana I would never

52 compare Adana with anywhere else but I can compare Istanbul with it

53 Işll: $h \mathrm{~mm}$

By comparing the two cities in this account, Mert makes another translocal connection. Adana, where Mert was born, is a large city in Southeast Turkey, and apparently, it seemed to be incomparable to even Berlin in Mert's imagination. He does not particularly address the size of the city here, but it seems to be more about the vibrancy of this city that lead Mert into thinking this way. In this sense, the local scale that he situates himself that was depicted in the previous section seems to be in play in his translocal account, too. His approach to İstanbul as a first timer, meanwhile, sounds more like an outsider's approach. In line with Ms. Kaya's take depicted above, Mert approaches İstanbul as a tourist, a consumer of what the city has to offer. He clarifies this later in the interview:

54 Mert: İstanbulda kendimi böyle yabancı bi sehirdeymişim gibi hissetim yani (.) Türkiyeye

55 ait değilmiş gibi hissettim

56 Işll: dünya şehri gibi di mi?

57 Mert: aynen [...] başka insanlar da yani başka ülkelerden gelen insanlar da çok olduğu için

58 [...] bi değişik bi şey oldu benim için

54 Mert: actually in Istanbul I felt like I was in a foreign city I mean (.) I felt as if it did not

55 belong to Turkey

56 Işl: like a world city right?

57 Mert: exactly [...] as there were other people I mean many people from other countries too

58 [...] it was something different for me

Mert's way of describing how he situates himself in İstanbul is worth attention here. He simply describes the world-city quality of İstanbul in his own words, by pointing to feeling like a foreigner, or seeing people from other countries. This take is quite different from his take on Berlin depicted in the previous section. He does not reflect his way of approaching Istanbul as a local anymore. 
Similar accounts have come from Simla, who used the exact same expression in describing her feelings about being in Antalya, another large city on the southern coast of Turkey known to be touristy. Simla compares Antalya with her family's hometown Kayseri, a conservative central Anatolian city, which is where she feels more like being in Turkey:

59 Işll: Türkiye'yi bu sefer nasıl gördün? farklı gördün mü?

60 Simla: evet ben zaten Alanyada kendimi hiç Türkiyede hissetmedim Antalyada falan

61 kendimi hiç Türkiyede hissetmiyorum [...] Kayseriye gidince daha da değişiyo orda ancak

62 Türkiyede olduğumu hissediyorum

59 Işll: How did you perceive Turkey this time? any different?

60 Simla: yes in Alanya I didn't feel like I was in Turkey at all I don't feel like I'm in Turkey

61 When I'm somewhere like Antalya [...] this changes when I go to Kayseri only there I feel

62 that I'm in Turkey

These three places seem to evoke different senses of translocality in Simla's narratives. While she understands the more cosmopolitan quality of touristic towns, she also relates being in Turkey more easily with being in her family hometown.

Large cities like Istanbul, Antalya, or Adana find place in these narratives in terms of being cosmopolitan places that the students feel more attachment to. Students' references to these cities point to their awareness of the translocal scales that they situate themselves within. As much as feeling a sense of attachment to Berlin at a local scale, their neutral approach to the large cities in Turkey that are not their families' hometowns suggest their revised understanding of homeland connections. As analyzed in the first section above, this contributes to their identity construction as global citizens. They are aware of the differences across hometowns and other towns, smaller cities and big cities, and similarities between big cities although they are in different countries. This awareness of translocality seems to be a part of their identities that was not so pronounced in their parents' generation. Besides a sense of place and belonging, they also construct this identity through their linguistic resources. At this point, their take on English as a Lingua Franca deserves closer attention, which I will do next.

\subsection{Being Transnational Users/Speakers of ELF}

Turkish migration to Germany has been continuing for more than 60 years now, and each generation has developed its own set of living habits in the transnational scale. An important pattern change has been in terms of their ways of spending summer vacation in Turkey. A remarkable number of Turkish families now own more property on the coasts where they spend most of their time in the summer, and visit their hometowns much less for their family obligations. This generational change has led into new patterns of living in Turkey. 
In relation to living in cosmopolitan places rather than their grandparents' hometowns, speaking English on their holidays in Turkey find a place in almost all the participants' narratives. In most cases, they narrate stories of meeting up with tourists from other countries in their holidays in Turkey. Simla describes this in the context of narrating her family's summerhouse in Antalya, where they have Russian neighbors. She talks about her friendship with her Russian peers that she constructed in English. This narrative then reminds her of an anecdote in Berlin that she just went through:

63 Simla: ben de çok İngilizce konuştum mesela Rus komşularımız olduğu için Rusça iki

64 kelime biliyorum fazla bilmiyorum yani iki tane kelime o kadar kelime arasında ama

65 İngilizce mesela iyi konuşuyodum (.) konuşuyodum (.) karşımdaki anlamıyodu ama

66 karşımdakinin İngilizcesi yetersiz mecburen böyle el hareketleri falan

67 Işıl: evet senden daha iyi konuşan biriyle konuşsan çaba sarfedersin

68 Simla: evet dün zile basıp durdular çöp atmaya gidiyodum bi gürültü patırtı çocuklar

69 zannettim was ist los diyodum bi baktım karşımda kadın I'M SORRY I'M LOSING MY

70 KEY dedi OKAY NO PROBLEM dedim kadın böyle titriyodu

63 Simla: and I spoke a lot of English too for example as we have Russian neighbors I know

64 two words of Russian not much I mean two words among all words but English for

65 example I spoke (.) spoke well (.) the person talking to me would not understand his

66 English is insufficient so we're bound to use gestures and the like

67 Işl: yes if you speak to somebody who speaks better than you you put some effort

68 Simla: yes yesterday they kept on ringing the bell I was going outside to throw away the

69 garbage there was noise suddenly I thought it was children I said what's going on and

70 suddenly there was a woman in front of me I'M SORRY I'M LOSING MY KEY she said and I said OKAY NO PROBLEM she was shaking

The brief exchange Simla had with the stranger at their doorstep in Kreuzberg that she quoted in English seems to be a regular daily exchange that people living in a multi-ethnic neighborhood of a global city can experience. The reason why Simla brings this up at this point in the conversation is to draw an analogy to her experience in Antalya, where she speaks better English than her Russian neighbors, according to her account. In both of her examples, Simla does not only draw on the transnational scale of various encounters, but also on being an ELF user/speaker. While she perceives her English better than her interlocutors in both situations, she continues to make a grammatical tense error in quoting her (I'm sorry, I'm losing my key).

English as spoken in the summer in Turkey has found place frequently in Mert's narratives, too. Like Simla, Mert's family has a separate summerhouse than their hometown residences. In one of my first interviews with him, he gives the following account:

71 Mert: ben İngilizce'yi yazlıkta falan konuşuyorum

72 Işl: sen onu anlatıyodun evet

73 Mert: İngilizce zaten bence derste öğrenilmez ya: dışarda öğrenilir bence gramatiği

71 Mert: I speak English at the summerhouse and the like

72 Issl: you told me about it before yes 
73 Mert: you cannot learn English in class if you ask me you learn it outside I think its grammar

Besides clearly locating the context where he speaks English the most, Mert's account also reveals how he conceptualizes the summerhouse in Turkey as a natural extension of his life. He makes the point that English is best learned outside class, particularly its grammar. Here, he probably refers to the acquisition of English grammar rather than its explicit learning in class. Mert further continues with his take on English:

74 Mert: İngilizcem yani İngilizceyi Türkçeden bile daha çok seviyorum öyle söyliyim

75 Işıl: hmm

76 Mert: bilmiyom yani şey bi dil olduğu için dünya dili [olduğu için

77 Işl: [dünya dili hmm

78 Mert: yani herkesin anlaşçağı bir dil olarak kolay bi dil Türkçeden de kolay Almancadan

79 daha da kolay

80 Ișl: hı hı o kesin

81 Mert: ondan sonra kulağa da hoş geliyo

82 Ișll: hmm

74 Mert: my English I mean I like English even better than Turkish let me put it that way

75 Işıl: $\mathrm{hmm}$

76 Mert: I don't know like it's kind of a world language I mean lit is

77 Ișl: $\quad$ [world language $\mathrm{hmm}$

78 Mert: I mean it's an easy language as far as everybody's communication is concerned easier

79 than Turkish and much easier than German

80 Işll: huh huh that's for sure

81 Mert: and also it sounds nice

82 Işıl: $h m m$

In this account, it is remarkable how Mert constructs his takes on Turkish and German, his two native languages, and English. Apparently, the world language quality of English is what impresses Mert the most. This goes in parallel to his take on being residents of a global city and living translocally as depicted above. He also adds the ease of learning English and that it sounds nice to the ear, as the other two reasons why he thinks that way, which indicate his positive approach to learning and speaking English.

As transnational individuals, the participants imagine and depict the role of English in their lives as relevant to their mobility. It is very natural for them to separate spaces for using English within these lives. It is also natural for them to recognize themselves as users/speakers of ELF in Berlin, who can run into other users/speakers of ELF anytime within the scale of their transnational lives. These accounts are in parallel to the participants' self-positioning at the local scale of Berlin and the translocal scale of homeland connections.

\section{Discussion and Conclusion}


This paper has sought to investigate how identity construction in ELF contexts could be situated within the larger transnational experience of multilingual students. The first two sections have depicted the local and translocal scales that inform participants' constructions of attachment to their city and the changing meanings of homeland for them. Against this background, the third section focused on the transnational scale, which participants construct through being users/speakers of ELF. While being users/speakers of ELF in this context is inherently related to being transnational, it also appears as inseparable from the speakers' self-positioning as global citizens and their connections with the homeland, both of which are constructed through multilingual resources. Living in Berlin, or in a neighborhood in Berlin, requires exploiting these resources on a daily basis. Likewise, changing perceptions of the homeland is related to the speakers' exploiting of multilingual resources as much as their changing relationship with the Turkish language compared to their parents' generation. As depicted in detail in Erduyan (2014), speaking more standard forms of Turkey-Turkish is one of the many ways this relationship is enacted.

Identity construction in ELF contexts need to be perceived from a wider perspective than being confined to the limits of English in order to achieve a fuller understanding of their role in multilingual repertoires. Research on identity in SLA and its related disciplines has so far centered on a myriad of ways to analyze linguistic practices. A similar expansion in ELF research might help broaden the field to fit the more encompassing research framework of multilingualism and attend to the linguacultures more closely.

This paper has sought to contribute to the understanding of the linguistic identity construction of ELF users/speakers from a more holistic perspective. In this vein, it has demonstrated ELF users/speakers' self-positioning within the transnational experiences that they go through in the form of claiming global citizenry and constructing different relationships with the homeland. Further research might illuminate how exactly these links are reflected in EFL practices.

\section{References}

Blommaert, J. (2010). The sociolinguistics of globalization. Cambridge: Cambridge University Press.

Canagarajah, S., \& De Costa, P. I. (2016). Introduction: Scales analysis, and its uses and prospects in educational linguistics [Special Issue]. Linguistics and Education, 34, 1-10.

Catedral, L. (2017). Discursive scaling: Moral stability and neoliberal dominance in the narratives of transnational migrant women. Discourse \& Society, 29(1), 23-42.

Erduyan, I. (2014). Competing discourses in the classroom: Turkish instruction in Berlin. BILIG-Journal of Social Sciences of the Turkish World, 70, 153-180.

Erduyan, I. (2017). Shifting timescales in peer group interactions: A multilingual classroom perspective. Innovation in Language Learning and Teaching, 11(3), 219-229. 
Erduyan, I. (2019). Multilingual Construction of Identity: German-Turkish Students at School. Fulda University CINTEUS-Center for Intercultural and European Studies Publications. Hannover: Ibidem Verlag. ISBN: 9783838212012

$\mathrm{Gu}, \mathrm{M}$. (2018). Identity construction and scale making of migrant university students in multilingual settings: a scalar analysis. International Journal of Bilingual Education and Bilingualism.

House, J. (2003). English as a lingua franca: A threat to multilingualism? Journal of Sociolinguistics, 7(4), 556-578.

Jenkins, J. (2015). Repositioning English and multilingualism in English as a Lingua Franca. Englishes in Practice, 2(3), 49-85.

Jessner, U. (2006). Linguistic awareness in multilinguals: English as a Third Language. Edinburgh: Edinburgh University Press.

Lam, W. S. E. (2009). Multiliteracies on instant messaging in negotiating local, translocal, and transnational affiliations: A case of an adolescent immigrant. Reading Research Quarterly, 44(4), 377-397.

Lemke, J. L. (2000). Across the scales of time: Artifacts, activities, and meanings in ecosocial systems. Mind, Culture, and Activity, 7(4), 273-290.

Maloney, J., \& De Costa, P. I. (2017). Imagining the Japanese heritage learner: A scalar perspective. Language, Discourse, \& Society, 9(1), 35-52.

May, S. (Ed.) (2014). The multilingual turn: Implications for SLA, TESOL, and bilingual education. London and New York: Routledge.

Seidlhofer B. (2017) English as a Lingua Franca and Multilingualism. In: Cenoz J., Gorter D., May S. (eds) Language Awareness and Multilingualism. Encyclopedia of Language and Education (3rd ed.) (pp.391-404). Springer, Cham.

Wortham, S. (2003). Curriculum as a resource for the development of social identity. Sociology of Education, 76(3), 228-246. [Special Issue: Sociology of School and Classroom Language].

Wortham, S. (2004). From good student to outcast: The emergence of a classroom identity. Ethos, 32, 164-187.

Wortham, S. (2006). Learning identity: The joint emergence of social identification and academic learning. New York: Cambridge University Press.

\title{
Appendix A. Transcription conventions:
}

\author{
Turkish originals: regular case \\ German originals: bold case \\ English orignals: $\quad$ CAPITAL LETTERS \\ English translations: italics \\ (.) short pause \\ (x.0) x seconds \\ (...) omitted speech \\ $>\mathrm{xx}<$ fast tempo \\ $>>\mathrm{xx}<<\quad$ very fast tempo \\ $\mathrm{xx}-\quad$ abortion of utterance \\ $=\mathrm{xx}$ fast connection \\ [...] commentary \\ $:$ : phonemic lengthening \\ ${ }^{\circ}$ low ${ }^{\circ}$ low volume \\ ${ }^{\circ}{ }^{\circ}{ }^{\circ}{ }^{\circ \circ}$ very low volume \\ underlined high volume
}




\section{Copyrights}

Copyright for this article is retained by the author(s), with first publication rights granted to the Journal.

This is an open-access article distributed under the terms and conditions of the Creative Commons Attribution license (CC BY-NC-ND) (http://creativecommons.org/licenses/by-nc-nd/4.0/). 